\title{
APPLICATION OF HEC-HMS AND IBER IN THE NUMERIC MODELING OF FLOODS IN THE RIO SAN SEBASTIAN OF THE MUNICIPALITY OF TOTOLAPAN, MORELOS, MEXICO
}

\author{
JORGE VÍCTOR PRADO-HERNÁNDEZ ${ }^{*}$, FERMÍN PASCUAL-RAMÍREZ ${ }^{2}$, \\ DAVID CRISTÓBAL-ACEVEDO ${ }^{1}$, ÓSCAR GERARDO VALENTÍN-PAZ ${ }^{3}$, \\ MAURICIO CARRILLO-GARCÍA ${ }^{4}$, ANTONIO MARTÍNEZ-RUÍZ ${ }^{4} \&$ \\ JESUS JOSE FERNANDO SÁNCHEZ-MORALES ${ }^{5}$ \\ ${ }^{1}$ Soils Department, University of Chapingo, México \\ ${ }^{2}$ Research Institute on Ecosystems and Sustainability (IIES), UNAM, Campus Morelia, México \\ ${ }^{3}$ Irrigation Department, University of Chapingo, México \\ ${ }^{4}$ National Institute of Forestry, Agriculture and Livestock Research (INIFAP), México \\ ${ }^{5}$ Postgraduate College, Texcoco, México
}

\begin{abstract}
In recent times, the floods in urban areas in Mexico have occurred frequently and one cause is the presence of extreme precipitation events. Recently, part of the urban area of the municipality of Totolapan, Morelos was flooded by the river San Sebastian's overflow. Consequently, the aim of the present work was to carry out a numeric modeling of the water behavior in the river San Sebastian in order to know the possible areas affected by flooding. The HEC-HMS hydrological method was used to calculate the runoff hydrographs for different return periods and the two-dimensional hydraulic model Iber was used for modelling the water run through the riverbed. Modelling showed the areas and the floodable surface in the return periods considered, indicating the degree of affectation using maximum flow depth maps. The results can be useful for disaster prevention caused by surface runoff. Keywords: overflow of channels, hydraulic modeling, transient flow, drone application, surface runoff.
\end{abstract}

\section{INTRODUCTION}

Inadequate management of water resources is one of the most serious problems that modern populations have to face. Among the principal causes are poor urban planning, inadequate use of the soil and the presence of the extraordinary precipitation events [1], [2]. As a result, floods occur and damages of diverse nature, both material and health or even human losses.

Annually, in Mexico severe damage occurs by floods caused by different meteorological events (winter and summer rainfalls, hurricanes, tropical depressions, cyclones and cold fronts); in the period from 1943 to 2007, 4,183 deaths, 7,520,000 affected people and 5,532 millions of dollars are conservatively estimated as material damages [4], [5].

The municipality of Totolapan, Morelos, has been affected at different times by extreme hydrometeorological phenomena, causing the growth and overflow of the river which runs through the municipality, affecting different housing, mainly in San Sebastian and Totolapan neighborhoods. To prevent and mitigate disasters caused by extraordinary surface runoff in the San Esteban River, the hydrological response of the runoff area and the hydraulic behavior of the main channel must be known.

Mathematical modeling shows that it's a useful tool to prevent and minimize the losses caused by floods, because it allows to predict accurately the behavior of hydrological variables in runoff areas and the hydrodynamic behavior in free surface flow [6], [7]. Using hydrological modeling, the effects of the land use change and extreme precipitation events in

* ORCID: http://orcid.org/0000-0001-6045-1661 
the surface runoff can be represented [1], and, using hydraulic modeling, the temporal and spatial evolution of the flow and the depth in the riverbed and flood areas can be represented [8]-[10]. Therefore, the systematic application of tools for the physiographic representation of urban basins, together with distributed hydrological models and hydraulic models constitute a dynamic analysis instrument and hydraulic diagnosis, which would allow early decision making in order to avoid or minimize damages caused by the floods [6], [7].

The joint use of the HEC-HMS hydrological model and hydraulic models is one of the most used methodologies to represent the floods caused by channels overflow [11], [12]. The HEC-HMS model is applied in different parts of the world with acceptable results in the estimation of surface runoff in basins [13], [14] and it is proposed as an alternative for basins without hydrometry [15], also it can be applied in Mexico where the measurement is poor [16].

Recently, Iber numeric model was developed to model non-permanent two-dimensional turbulent flow in rivers and estuaries [17] and it is available for free on the internet [18]. Due to its recent development, it's little used and known about in America, but it's convenient to consider it because its results are similar to those obtained in the two-dimensional HEC-RAS model [19]. It's remarkable free obtaining contrasts with the expensive numerical models licenses with similar characteristics like FLO2D or MIKEFLOOD.

A numerical modelation with HEC-HMS and Iber models was done to quantify the affected area by floods and identify the vulnerable zones, in the municipality of Totolapan, Morelos, caused by river San Sebastian's overflow. This will allow planning urban growth and order land use, identifying river sites that hinder the flow of water and those where protection walls should be built, as well as evacuating the population likely to be affected by flooding, caused by extreme rainfall. The HEC-HMS hydrological model was used to obtain the hydrographs of direct runoff for different return periods and Iber hydraulic model was used to model the evolution of the depths spatially and temporarily.

\section{MATERIALS AND METHODS}

\subsection{Description of the study area}

The municipality of Totolapan is geographically located in the north part of the State of Morelos at an altitude between 1,700 and 2,700 meters above sea level and an average annual precipitation of $1,115.9 \mathrm{~mm}$ [20]. The specific study area is located between the geographic coordinates ( $\left.98^{\circ} 55^{\prime} 41.53^{\prime \prime} \mathrm{W}, 18^{\circ} 58^{\prime} 40.14^{\prime \prime} \mathrm{N}\right)$ and (98 55' 33.38" W, $\left.19^{\circ} 04^{\prime} 43.62^{\prime \prime} \mathrm{N}\right)$, in the San Sebastián River microbasin, named in honor of the name of the main stream.

\subsection{Definition of the hydraulic model}

The Iber two-dimensional model was used for hydraulic modeling of the study area, based on the two-dimensional differential equations of transient flow of Saint-Venant [17], obtained from the application of the conservation laws of mass (eqn (1)) and momentum (eqns (2) and (3)) in which they incorporated the effects of turbulence and surface friction due to wind:

$$
\frac{\partial h}{\partial t}+\frac{\partial h U_{x}}{\partial x}+\frac{\partial h U_{y}}{\partial y}=0
$$




$$
\begin{gathered}
\frac{\partial}{\partial t}\left(h U_{x}\right)+\frac{\partial}{\partial x}\left(h U_{x}^{2}+g \frac{h^{2}}{2}\right)+\frac{\partial}{\partial y}\left(h U_{x} U_{y}\right)=-g h \frac{\partial Z_{b}}{\partial x}+\frac{\tau_{s, x}}{\rho}-\frac{\tau_{b, x}}{\rho}+\frac{\partial}{\partial x}\left(v_{t} h \frac{\partial U_{x}}{\partial x}\right)+ \\
\frac{\partial}{\partial y}\left(v_{t} h \frac{\partial U_{x}}{\partial y}\right), \\
\frac{\partial}{\partial t}\left(h U_{y}\right)+\frac{\partial}{\partial y}\left(h U_{y}^{2}+g \frac{h^{2}}{2}\right)+\frac{\partial}{\partial x}\left(h U_{x} U_{y}\right)=-g h \frac{\partial Z_{b}}{\partial y}+\frac{\tau_{s, y}}{\rho}-\frac{\tau_{b, y}}{\rho}+\frac{\partial}{\partial x}\left(v_{t} h \frac{\partial U_{y}}{\partial x}\right)+ \\
\frac{\partial}{\partial y}\left(v_{t} h \frac{\partial U_{y}}{\partial y}\right),
\end{gathered}
$$

where $h$ is the water depth (m), $U_{x}$ and $U_{y}$ are the average flow velocities in the $x$ and $y$ directions $\left(\mathrm{m} \mathrm{s}^{-1}\right), g$ is the acceleration due to gravity $\left(\mathrm{m} \mathrm{s}^{-2}\right), \rho$ is the water density $\left(\mathrm{kg} \mathrm{m}^{-3}\right)$, $Z_{b}$ is the canal bottom elevation $(\mathrm{m}), \tau_{s}$ is the friction in the free surface due to rubbing with the wind, $\tau_{b}$ is the friction due to rubbing with the canal bottom calculated with the Manning equation and $v_{t}$ is the turbulent viscosity.

For the numeric solution of these equations were defined: the topographical, geometrical and physical characteristics of the channel and the flood zones, initial and boundary conditions and a simulation period.

\subsubsection{Initial conditions}

As an initial condition, it was considered a zero flow in the channel because in recent years it has not presented a base flow. Manning's Roughness Coefficients were assigned according to the characteristics of the riverbed walls and the surface of the surrounding area [21], according to a detailed visual inspection of the water current and the flood zone.

\subsubsection{Boundary conditions}

Boundary conditions upstream were the hydrographs obtained by the hydrological modelation with the HEC-HMS model for return periods of 2, 5, 10, 25, 50, 100 and 500 years (T2, T5, T10, T25, T50, T100 and T500). As a boundary condition downstream was used a table of values of dimensions of the surface of the water and its corresponding flows, considering a normal subcritical flow, assumed by the conditions observed in the channel, obtained through field inspections and for the information provided by the villagers.

\subsection{Topography of the channel of the Río San Sebastián and the flood zone}

It was obtained by a combination of a digital model, generated from information obtained through a drone and a topographic survey with Total Station (Fig. 1).

Photographs of the study area, the channel and the surrounding and flood area were taken vertically with a DJI F550 drone, at one second intervals at 100 meters height, on sunny days and without wind. The drone was equipped with a Canon Power Shot camera with normal color cartographic and dual frequency GPS receivers with an accuracy (static method) of 3 $\mathrm{mm} \pm 5 \mathrm{ppm}$ and $5 \mathrm{~mm} \pm 5 \mathrm{ppm}$, in planimetry and altimetry, respectively.

The photographs obtained were processed by Pix4Dmapper software, which is available for free on internet [22], to obtain a detailed topography of the land adjacent to both banks of the San Sebastián River and the location of the channel.

With Total Station, the geometry and topography of the principal channel was obtained because the abundant vegetation did not allow to have detailed information with the drone. Topographical surveys were made in the cross sections of the riverbed in sites with significant changes in the geometry (transverse direction to the flow and plan view) and bed slope. 


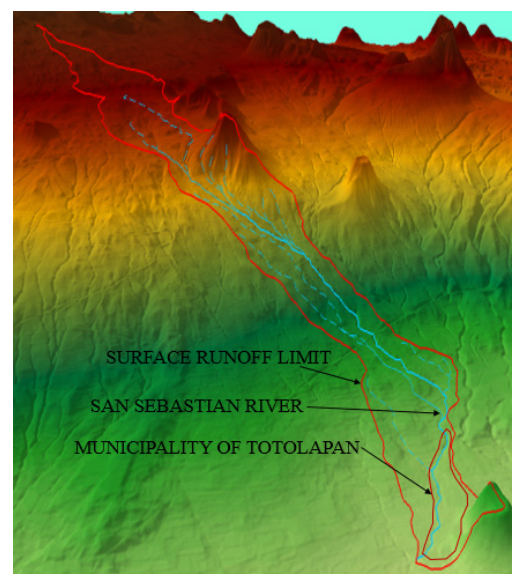

(a)

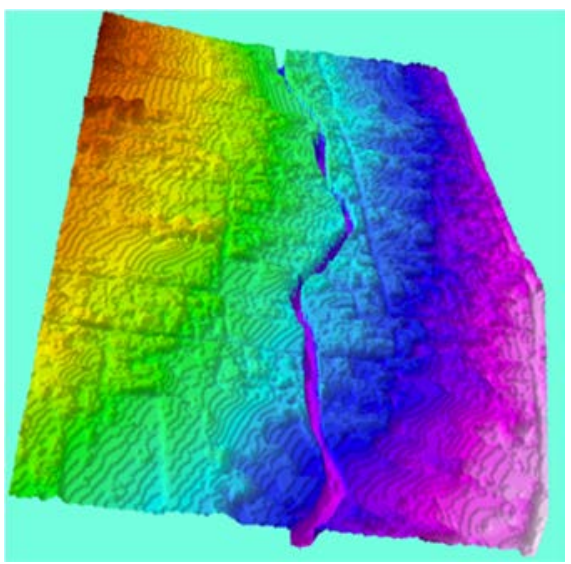

(b)

Figure 1: Topography of San Sebastían River watershed. (a) Drainage network; (b) Main stream at urban area.

\subsection{Precipitation databases}

For obtaining precipitation information, the inventory of weather stations and the daily climatological database of CLICOM of the National Weather Service of Mexico were consulted through web platform of the Scientific Research Center and Higher Education of Ensenada, Baja California [23].

Due to in several weather stations did not find full information of precipitation in some years, it was considered as a source of information only those which have a minimum of $15 \%$ of missing data.

\subsection{Methods for estimating missing data}

For estimating missing data, inverse distance weighting method was used, it was proposed by the US National Weather Service, which has been verified theoretically and empirically in hydrological and geographical studies [24], [25]. This method considers that the missing data in a certain station can be estimated based on the data observed in the surrounding stations and it can be applied on a daily, monthly or annual basis.

\subsection{Obtaining the distribution of maximum precipitations for 24 hours}

First of all, the maximum precipitations in 24 hours expected were calculated for each of the return periods considered and then multiplied by the coefficients proposed by [25] (Table 1), to obtain its cumulative distribution throughout the 24 hours.

Table 1: Coefficients to relate a rain to a rain of 24 hours of duration.

\begin{tabular}{|l|c|c|c|c|c|c|c|c|c|c|}
\hline $\begin{array}{l}\text { Duration of the } \\
\text { rain (hours) }\end{array}$ & 1 & 2 & 3 & 4 & 5 & 6 & 8 & 12 & 18 & 24 \\
\hline Coefficient & 0.30 & 0.39 & 0.46 & 0.52 & 0.57 & 0.61 & 0.68 & 0.80 & 0.91 & 1.00 \\
\hline
\end{tabular}




\subsection{Generation of curves of intensity-duration-frequency}

With the information of the previous paragraph an empirical functional relationship of intensity-duration-frequency (IDF) was obtained to explain the rain intensity (I) depending on its duration $(t)$ and the return period $(\mathrm{T})$ [26], [27].

\subsection{Generation of design hyetographs}

With the obtained IDF functional relation, IDF curves were generated for each of the return periods considered, for a one-hour duration that corresponded to the time of concentration of the runoff which was calculated with the Kirpich empirical equation [27], using the physical characteristics of the main channel.

With the IDF curves generated for one hour the design hyetographs were made and corresponded to the maximum precipitation events for the return periods considered. Alternating block method was applied, taking the rain intensity of the IDF curves to obtain the corresponding precipitation depth, multiplying the intensity of the rain by its duration [21]. In this way, the temporal distribution of rainfall corresponding to each of the analyzed return periods was obtained to determinate surface runoff in the form of hydrographs using hydrological modeling.

\subsection{Definition of the hydrological model}

Hydrological modeling of the study area was made through software HEC-HMS 4.1. In the model settings, the following aspects were considered: design hyetographs were used as input, evapotranspiration was considered null because they are short term events, retentions for foliage were considered null for lack of information; the retention by small depressions was considered null because of the slope of the ground surface is more or less uniform; and finally, the conversion of the runoff depth to an output runoff hydrograph was made through Synthetic Unit Hydrograph of the SCS because it is the suggested method for Mexico [27].

The runoff depth was determined by Curve Number $(\mathrm{CN})$ method of the Soil Conservation Service of EE. UU. due to several studies show acceptable results [13], [15], [28].

The CN values were assigned according to the values suggested by SCS method, considering soil conditions, coverage and land use [21], [27], [29].

The initial abstraction $\left(I_{a}\right)$ of the soil was considered about $20 \%$ of the maximum abstraction of the soil (S), suggested proportion by SCS [30] for runoff basins with high rainfalls like in Totolapan [20]. This concept refers to the portion of the precipitation that does not produce runoff and it was calculated with the eqns (4) and (5) [29], where $I_{a}$ and $S$ are in millimeters

$$
\begin{gathered}
I_{a}=0.2 *\left(\frac{25400}{C N}-254\right), \\
S=\left(\frac{25400}{C N}-254\right) .
\end{gathered}
$$

SCS proposes to consider the delay time equal to $60 \%$ of the concentration time $\left(t_{c}\right)$. It was calculated with Kirpich equation [31] that is recommended to use for Mexico, and it expresses like [27]:

$$
t_{c}=0.02 * \frac{L^{1.15}}{H^{0.385}}
$$


where $t_{c}$ means concentration time $(\mathrm{min}), L$ means longest watercourse length in the watershed (m), and $H$ means the difference in elevation between the outlet of the watershed and the hydraulically most remote point in the watershed (m).

\section{RESULTS AND DISCUSSION}

\subsection{Design hyetographs}

Only five weather stations within a radio less than $30 \mathrm{~km}$ from the supply basin of surface runoff to the San Sebastian River met the criteria of available information established in the methodology. One of them, called Totolapan, Morelos is located inside the basin and the rest is outside of it. Due to the remoteness of the weather stations located abroad, these were largely unrepresentative of the precipitation in the study basin, therefore only the Totolapan station information was considered with $3.6 \%$ of missing data.

The extreme precipitation annual values in 24 hours during the period of 1981 to 2011, were fitted to a function of Gumbel probability distribution [32], obtaining the corresponding values to the return periods analyzed (Table 2).

Table 2: Probable extreme precipitation in 24 hours in the study basin for different return periods.

\begin{tabular}{|c|c|c|}
\hline $\begin{array}{c}\text { Return period } \\
\text { T (years) }\end{array}$ & Probability of occurrence & Precipitation (mm) \\
\hline $\mathbf{2}$ & 0.50 & 77.14 \\
\hline $\mathbf{5}$ & 0.80 & 104.84 \\
\hline $\mathbf{1 0}$ & 0.90 & 123.18 \\
\hline $\mathbf{2 5}$ & 0.96 & 146.35 \\
\hline $\mathbf{5 0}$ & 0.98 & 163.55 \\
\hline $\mathbf{1 0 0}$ & 0.99 & 180.61 \\
\hline $\mathbf{5 0 0}$ & 0.99 & 220.04 \\
\hline
\end{tabular}

The empirical equation for rain intensity $\left(\mathrm{I}, \mathrm{mm} \mathrm{h}^{-1}\right)$, resulted on the basis of the return period (T, years) and the duration of the rain ( $t$, minutes), with a good adjustment $\left(R^{2}=0.94\right)$ and its expression is given by the eqn (7).

$$
\mathrm{I}=\frac{291.5134 * \mathrm{~T}^{0.184254}}{t^{0.61885}}
$$

With the eqn (7) IDF curves and design hyetographs were generated, using rain durations of 5 to 60 minutes, at 5-minute intervals (Fig. 2). At the beginning and the end of the 60minute period the precipitations were low, observing maximum values at 30 minutes. In the IDF curves it was observed that the greater the duration of the storm, the lower its intensity, and as the return period increases, so does the intensity.

\subsection{Hydrological modeling}

Hyetographs in Fig. 2 were used for the runoff hydrological modeling and a concentration time of 56.7 minutes, as a result of replacing in the eqn (6) a length of 9,172 $\mathrm{m}$ and a slope of $740 \mathrm{~m}$ of the main channel of the River San Sebastian. It was used a numerical curve value weighted by the area of 66.8, as a result of three land uses with different surfaces (Table 3 ). 


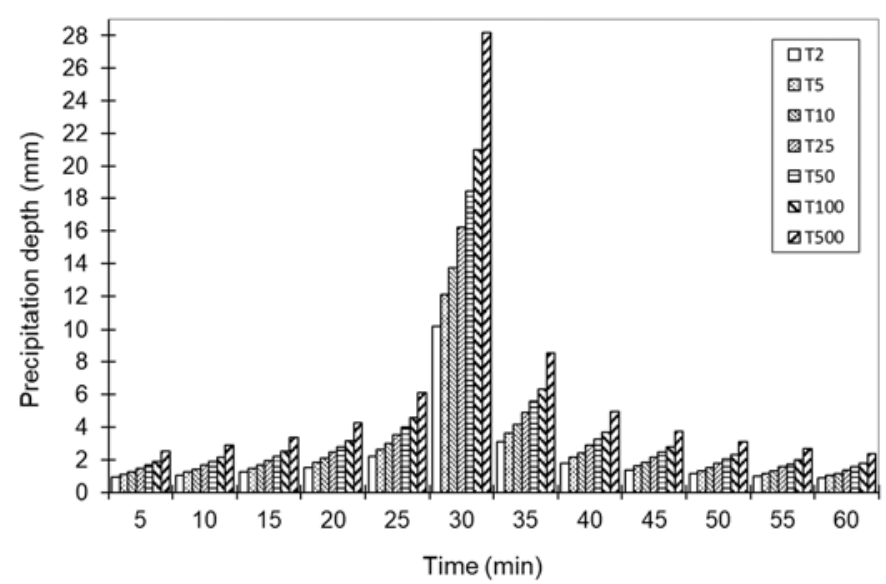

Figure 2: Design hyetographs for return periods (T) considered.

Table 3: CN values of the study zone.

\begin{tabular}{|c|c|c|c|c|c|c|}
\hline Zone & Land use & $\begin{array}{c}\text { Hydrological } \\
\text { condition }\end{array}$ & $\begin{array}{c}\text { Soil } \\
\text { group }\end{array}$ & Area (ha) & CN & $\begin{array}{c}\text { CN } \\
\text { weighted }\end{array}$ \\
\hline 1 & Forest & Regular & C & 293 & 50.0 & \multirow{2}{*}{66.8} \\
\cline { 1 - 5 } 2 & Urban area & Regular & C & 30 & 79.0 & \\
\hline 3 & Farming & Regular & C & 526 & 75.5 & \\
\hline
\end{tabular}

As a result, maximum runoff hydrographs were obtained for the study return periods (Fig. 3 ); it is clearly shown that as the return period increases, the maximum runoff increases. As a result, maximum flow rates of 1.5, 2.1, 3.1, 5.4, 8.0,11.6, $24.9 \mathrm{~m}^{3} \mathrm{~s}^{-1}$ for $2,5,10,25,50$, 100 and 500 years of return period. The times of occurrence were 3.4 to $5.3 \mathrm{~h}$, for return periods of 2 and 500 years, respectively.

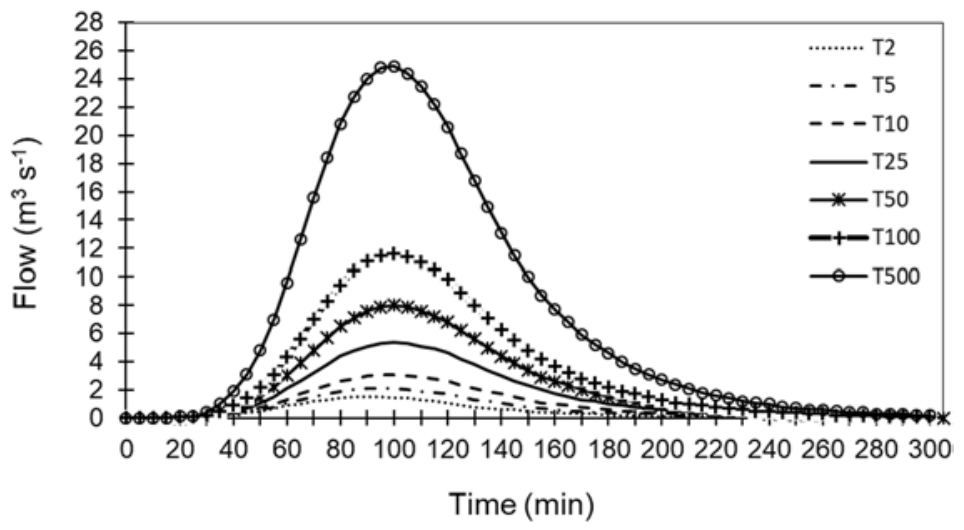

Figure 3: Maximum hydrographs expected for different return periods in the San Sebastian Riverbed. 


\subsection{Topography and geometry of the San Sebastian riverbed}

Georeferenced orthomosaics, digital surface models, digital terrain models and texture 3D models were obtained of the processing of the aerial images taken by the drone, with $3 \mathrm{~cm}$ of resolution each pixel, which was much better than those generated with the INEGI lidar models, whose resolution is up to $1 \mathrm{~m}$ per pixel [33].

Orthorectification was made with an overlap of $90 \%$, greater than $70 \%$ or smaller than the one used by INEGI due to the photos acquisition costs. This allowed to obtain an accuracy of millimeters on the vertical axis, while lidar business models offer at most an accuracy of $15 \mathrm{~cm}$ for Mexico [33].

Obtaining the topography with the support of a drone is a powerful and novel tool in Mexico, for the study of floods [34] because it allowed to identify with a good resolution the relief of the flood zone and the geometry of the channel, details that are impossible to obtain with the information offered by INEGI, and even more because it is a small river and some places with very flat surfaces.

\subsection{Considerations in hydraulic modeling}

With the identification of the physical characteristics of the surface of the riverbed walls and the surface of the ground of the adjacent area on both banks, shown in the Fig. 4, and that were obtained with the drone, Manning friction coefficients were assigned. A value of 0.025 was assigned to the river, 0.023 to the bare soil, 0.05 to the prairie, 0.12 to trees, 0.032 to urban vegetation, 0.08 to disperse vegetation, 0.18 to dense vegetation, 0.018 to concrete, 0.15 to residential area and 0.13 to agricultural surface [21].

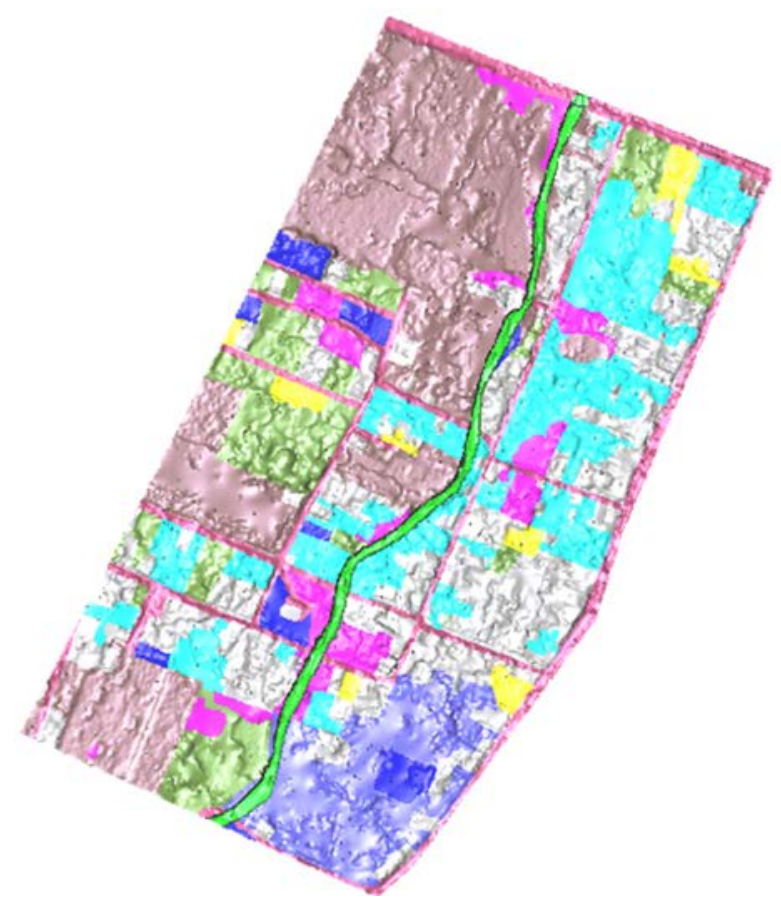

\section{River canal}

Soil without plant cover

Grassland

Trees

Urban vegetation

Scattered vegetation

Dense vegetation

Concrete cover

Residential area

Agricultural use

$\mathrm{Yb}$

Figure 4: Channel physical conditions to assign the roughness coefficient. 
Manning's friction coefficient, it is usually the adjustment parameter to calibrate hydraulic models, but in this study the assigned values were considered correct because the physical characteristics of the contact surface with water were identified with high resolution [35].

\subsection{Result of hydraulic model}

As a result of hydraulic modeling, flood depth maps for the return period considered were obtained. In them, the sites that would be affected by the Rio San Sebastian overflow were observed (Fig. 5). The affected areas are shown in the Table 4, that go from 0.63 to 2.77 ha, for return period of 2 and 500 years, respectively and correspond to 2.1 and $9.2 \%$ of the urban area of the municipality of Totolapan. As is evident, these values don't represent a large percentage of the total urban area; however, housings are located in the flood zone, currently occupied by the municipality people, who are very important.

Table 4: Affected areas and maximum depths expected in the urban zone of the municipality of Totolapan.

\begin{tabular}{|c|c|c|}
\hline Return period (years) & Area (ha) & Maximum depth (m) \\
\hline 2 & 0.63 & 4.95 \\
\hline 5 & 0.83 & 5.91 \\
\hline 10 & 1.06 & 6.73 \\
\hline 25 & 1.41 & 8.01 \\
\hline 50 & 1.74 & 10.52 \\
\hline 100 & 2.00 & 10.52 \\
\hline 500 & 2.77 & 12.17 \\
\hline
\end{tabular}
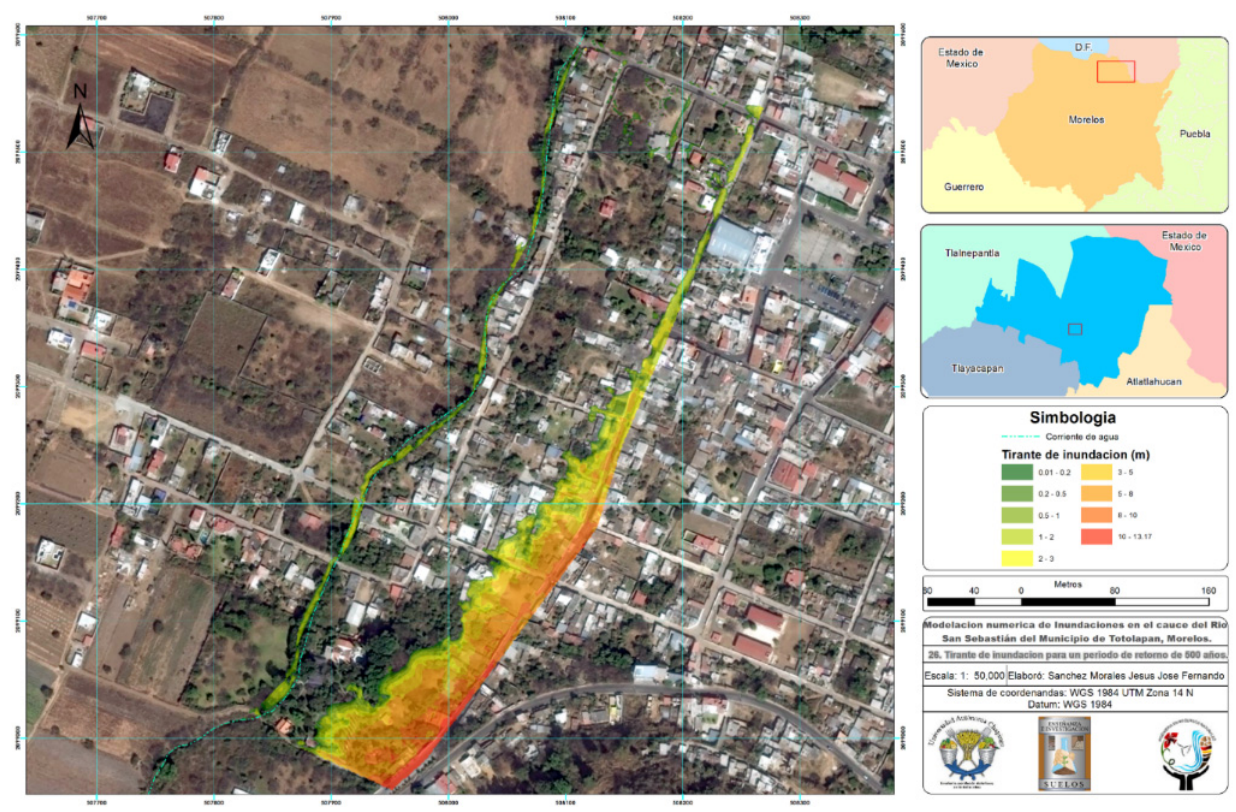

Figure 5: Flood depth for a return period of 500 years. 
In all return periods considered, the houses located on both sides of the Alarcon Norte Street would be affected, located parallel to the left bank of the river, in the San Sebastian neighborhood. The affected zone is located between Niño Perdido and Huezario streets; and it was found that as the return period of the runoff events increases, the affected area increased between Lic. Benito Juarez and Alarcon Norte streets. Lic. Benito Juarez street is the one closest to the river, but it is in a higher area.

Added to the extraordinary runoff events, the river overflow was due to the loss of the capacity of the conduction of the channel by the accumulation of sediments, for the invasion of the river banks with civil works and by the obstructions to the flow by vehicular bridges in the Niño Perdido, Callejo Juarez, Calle San Miguel streets and $88 \mathrm{~km}$ highway. These aspects were represented in the flow simulation through the geometry and topography of the main channel, and one aspect to consider should be the obstruction caused by the dumped garbage.

It's remarkable that even in the smaller extraordinary runoff events expected high depths would be presented $(4.95 \mathrm{~m})$ on Alarcon Norte street and represent a potential death threat to villagers.

The problems identified that increase flood risks suggest that we should make a territorial planning in the catchment, an improvement in urban planning and the adaptation of vehicular crossings. Different scenarios could be simulated with the support of the tool applied in this work so that its results, added to those obtained in this investigation, improve the prevention and mitigation of flood damages.

\section{CONCLUSIONS}

The surfaces and zones vulnerable to floods caused by the river San Sebastian overflow were determined, for hydrographs corresponding to seven return periods. The most vulnerable zone corresponded to the sites with the lowest topographic level, located on the left bank of the river and upstream of the vehicular crossing of the $88 \mathrm{~km}$ highway. The overflow causes were detected and should be attended to prevent and mitigate flood damages. A novel aspect of this kind of studies in Mexico, it was the inclusion of a much more accurate topography than that offered by government and the reliable assignment of friction coefficients, thanks to a drone support.

Under the current management conditions of the San Sebastián River watershed, the San Sebastián neighborhood of the municipality of Totolapan will be frequently flooded. To mitigate flooding, those responsible for planning and legislating water management should propose structural and non-structural actions in the watershed. They should: relocate the buildings that invade the banks of the river and ensure that they do not rebuild in this area, expand the cross-section of the vehicle bridges and study other alternatives to agricultural land use.

\section{REFERENCES}

[1] Akbari, A., Mozafari, G., Fanodi, M. \& Hemmesy, M.S., Impact of land use change on river floodplain using public domain hydraulic model. Modern Applied Science, 8(5), pp. 80-86, 2014.

[2] Fascículo Inundaciones 2014, Centro Nacional de Prevención de Desastres (CENAPRED). www.cenapred.gob.mx/es/. Accessed on: 7 Jan. 2017.

[3] Bitrán, D., Características del Impacto Socioeconómico de los Principales Desastres Ocurridos en México en el Período 1980-1999, CENAPRED: México, 2000.

[4] Fascículo de Inundaciones 2004, Centro Nacional de Prevención de Desastres (CENAPRED). www.cenapred.gob.mx/es/. Accessed on: 7 Jan. 2017. 
[5] Folleto Inundaciones 2009, Centro Nacional de Prevención de Desastres (CENAPRED). www.cenapred.gob.mx/es/. Accessed on: 7 Jan. 2017.

[6] Ahmad, S. \& Simonovic, S.P., An intelligent decision support system for management of floods. Water Resour. Manage, 20(3), pp. 391-410, 2006.

[7] Mobayed, K.N., Simulador de inundaciones en áreas urbanas: Un modelo de pronóstico con fines de alertamiento. CIENCIA@UAQ, 2(1),pp. 72-90, 2009.

[8] Cea, L., Legout, C., Darboux, F., Esteves, M. \& Nord, G., Experimental validation of a $2 \mathrm{D}$ overland flow model using high resolution water depth and velocity data. $J$. Hydrol., 513, pp. 142-153, 2014.

[9] Horritt, M.S. \& Bates, P.D., Evaluation of 1D and 2D numerical models for predicting river flood inundation. J. Hydrol., 268(1-4), pp. 87-99, 2002.

[10] Timbadiya, P.V., Patel, P.L. \& Porey, P.D., HEC-RAS Based hydrodynamic model in prediction of stages of lower Tapi River. ISH J. Hydraul. Eng., 17(2), pp. 110-117, 2011.

[11] Hernandez, T. \& Zhang, B., Floodplain analysis using computational tools. Proceedings of World Environ. and Water Resour., pp. 1-13, 2007.

[12] Knebl, M.R., Yang, Z.L., Hutchison, K. \& Maidment, D.R., Regional scale flood modeling using NEXRAD rainfall, GIS, and HEC-HMS/RAS: A case study for the San Antonio River Basin Summer 2002 storm event. J. Environ. Manage., 75(4), pp. 325-336, 2005.

[13] De Silva, M.M.G.T., Weerakoon, S.B. \& Herath, S., Modeling of event and continuous flow hydrographs with HEC-HMS: Case study in the Kelani River Basin, Sri Lanka. J. Hydrol. Eng., 19(4), pp. 800-806, 2014.

[14] Estrada, S.V. \& Pacheco, M.R.M., Modelación hidrológica con HEC-HMS en cuencas montañosas de la región oriental de Cuba. Ing. Hidráulica y Ambiental, XXXIII(1), pp. 94-105, 2012.

[15] Jeon, J.H., Lim, K.J. \& Engel, B.A., Regional calibration of SCS-CN L-THIA model: Application for ungauged basins. Water, 6, pp. 1339-1359, 2014.

[16] Datos Hidrométricos, Banco Nacional de Datos de Aguas Superficiales (BANDAS). www.conagua.gob.mx. Accessed on: 15 Jan. 2016.

[17] Bladé, E. et al., Iber: Herramienta de simulación numérica del flujo en ríos. Revista Internacional de Métodos Numéricos para Cálculo y Diseño en Ingeniería, 30(1), pp. $1-10,2014$.

[18] Manual de referencia hidráulico IBER: Modelización bidimensional del flujo en lámina libre en aguas poco profundas. Centro de Estudios y Experimentación de obras Públicas del Gobierno de España (CEDEX). http://iberaula.es/web/index.php. Accessed on: 7 May 2016.

[19] Lluen, C.W.E. \& Bladé, C.E., Aplicación de la nueva herramienta HEC-RAS 5.0 para cálculos bidimensionales del flujo de agua en ríos. Actas de las IV Jornadas de Ingeniería del Agua, pp. 155-164, 2015.

[20] Instituto Mexicano de Tecnología del Agua (ed.), Extractor Rápido de Información Climatológica ERIC III ver. 2.0. Jiutepec, Morelos, México, 2009.

[21] Chow, V.T., Maidment, D.R. \& Mays, W.L. (eds), Hidrología Aplicada, McGrawHill: Santa Fe de Bogotá, Colombia, 584 pp., 1994.

[22] Pix4Dmapper, Pix4D. https://pix4d.com. Accessed on: 16 May 2016.

[23] Centro de Investigación Científica y de Educación superior de Ensenada, Baja California, México (CICESE). http://clicom-mex.cicese.mx. Accessed on: 15 Feb. 2016. 
[24] Hubbard, K.G., Spatial variability of daily weather variables in the high plains of the USA. Agric. For. Meteorol., 68(1), pp. 29-41, 1994.

[25] Campos, A.D.F. (ed.), Procesos del Ciclo Hidrológico, Universidad Autónoma de San Luis Potosí: S.L.P., México, pp. 4-1-4-99, 1998.

[26] Témez, J. (ed.), Cálculo Hidrometeorológico de Caudales Máximos en Pequeñas Cuencas Naturales, Dirección General de Carreteras: Madrid, España, 111 pp., 1978.

[27] Aparicio, M.F. (ed.), Fundamentos de Hidrología de Superficie, Limusa: México, 303 pp., 2005.

[28] Sadeghi, S.H.R., Gholami, L., Darvishan, A.K. \& Saeidi, P., A review of the application of the MUSLE model worldwide. Hydrol. Sci. J., 59(2), pp. 1-11, 2014.

[29] US Department of Agriculture, Estimation of direct runoff from storm rainfall. National Engineering Handbook, US Department of Agriculture, NRCS, part 630 Hydrology. www.nrcs.usda.gov/wps/portal/nrcs/detail/mi/technical/engineering/?cid =nrcs141p2_024573. Accessed on: 7 Feb 2017.

[30] Woodward, D.E., Hawkins, R.H., Jiang, R., Hjelmfelt, A.T., Van Mullem, J.A. \& Quan, Q.D., Runoff curve number method: examination of the initial abstraction ratio. Proceedings of World Water \& Environ. Resour. Congress, pp. 1-10, 2003.

[31] Martínez, M.M. (ed.), Estimación de Variables Hidrológicas, SAGARPA: México, 26 pp., 2005.

[32] Domínguez, M.R., Arganis, J.M.L., Carrizosa, E.E., Fuentes, M.G.E. \& Echeverri, V.C.A. (eds), Determinación de Avenidas de Diseño y Ajuste de los Parámetros del Modelo de Optimización de las Políticas de Operación del Sistema de Presas del Río Grijalva: Informe Final, Comisión Federal de Electricidad (CFE): México, 2006.

[33] Imágenes Lidar, Instituto Nacional de Estadística, Geografía e Informática (INEGI). www.inegi.org.mx. Accessed on: 3 Mar. 2016.

[34] Cook, A. \& Merwade, V., Effect of topographic data, geometric configuration and modeling approach on flood inundation mapping. J. Hydrol., 377(1-2), pp. 131-142, 2009.

[35] Pappenberger, F., Beven, K., Horritt, M. \& Blazkova, S., Uncertainty in the calibration of effective roughness parameters in HEC-RAS using inundation and downstream level observations. J. Hydrol., 302(1-4), pp. 46-69, 2005. 